\title{
Om Grundtvigs menneskesyn
}

Foredrag på Liselund ved Grundtvig-Selskabets årsmøde 15. januar 1988.

af William Michelsen

Hvorfor er emnet "Grundtvigs menneskesyn" aktuelt i 1988? Man kan svare forskelligt; jeg vil svare følgende. Grundtvig blev næsten 89, og hans religiøse udvikling varede næsten til han blev 50 år gammel. Men gennem disse år indtog han en række forskellige standpunkter, der svarer til de standpunkter, som verden over nu er så uenige, at de kan føre til blodige krige som mellem Iran og Irak, oprørsbevægelser som i Pandjab i Indien, undertrykkelse af en hel race som i Sydafrika - fordi enhver religion kan synes at måtte være intolerant over for anderledestænkende og anderledestroende, hvis dens tilhængere er oprigtig troende. Også Grundtvig, der fra 1832 til sin død var urokkelig tilhænger af friheden til at tænke, tro og tale - både religiøst, politisk og videnskabeligt - har forud for 1832 været ikke blot yderliggående rationalist eller deist, men også intolerant fundamentalist. Hans religiøse udvikling kan derfor ses som et eksempel på, hvorledes det er muligt gennem et overskueligt tidsrum at nå frem til et alvorligt religiøst standpunkt, hvorfra man kan forstå anderledestænkende, fordi man selv har været igennem en tilsvarende fase eller periode i sin egen udvikling. Denne endelige holdning fra Grundtvigs side blev trods alt mødt med en sådan forståelse fra omgivelsernes side, at han ikke blot påny blev en anerkendt forfatter, prædikant og salmedigter, men at den bidrog til dén rummelige folkekirke og dén religiøse frihed, som Danmark stadig har. - Denne religiøse situation her i landet er måske ikke særlig beundringsværdig. Men den er - måske netop derfor - et karakteristisk eksempel på, hvorledes det er muligt at undgå de blodige sammenstød, som andre steder $\mathrm{i}$ verden gør tilværelsen meget vanskelig at udholde. 
Det er ikke selve denne holdning, dette foredrag skal handle om, men jeg vil gerne have sagt dette som indledning, for at foregribe nogle af de indvendinger man kan fremsætte mod det, jeg har at sige.

Grundtvigs menneskesyn er på én gang dobbelt og tredobbelt, idet han opfatter mennesket som legeme, ånd og sjcel, men således at han skildrer mennesket både som det oprindelig var, og som det er $n u$, dvs. både før og efter dét "store Uheld " (som det hedder $\mathrm{i}$ Indledningen til Nordens Mythologi 1832), hvorved mennesket mistede sin oprindelige harmoniske natur, og som man i datidens filosofiske og teologiske sprogbrug kaldte "Faldet" eller ligefrem syndefaldet. Det er dette store uheld, der skildres i myten om Adam og Eva i Paradiset, og hvordan de fristedes til at spise af frugterne på "Træet til Kundskab om Godt og Ondt" og faldt for denne fristelse.

Det mærkeligste ved denne myte er efter min mening, at det kun var af dette træ, de ikke måtte spise. - Hvorfor netop dette træ, som man dog skulde tro det var smukt og godt at spise af? Jo, svarer Slangen, det var fordi derved vilde de blive Guds lige, og det ønskede Gud ikke. - Men det var Løgn, siger Grundtvig. For det var netop hensigten med menneskets skabelse, at det skulde ligne Gud. Men denne lighed med Gud var ikke fuldstændig fra begyndelsen. Mennesket var kun "skabt i Guds Billede" - i den hensigt at det efterhånden, "gennem Tiden", skulde udvikle sig til et fuldkomment billede af Gud. Og denne hensigt blev ifølge Grundtvig ikke tilintetgjort af Djævelen ved menneskets fristelse og fald for fristelsen. Guds hensigt blev kun forvirret og forsinket.

Således er Grundtvigs opfattelse af mennesket i dets oprindelige natur og i dets nuværende forvirrede tilstand. Johannes Ewald skildrede det i sin "Ode til Sjælen" som en fjerløs ørneunge, der er faldet ud af reden. Grundtvig skildrer mennesket som et billede af den treenige Gud i dobbelt skikkelse som mand og kvinde, med evne til at elske hinanden og blive "eet Kød", som det heddeer i Bibelen, dvs. ét menneske, et barn med samme evne til at elske et andet menneske og således fortsætte udviklingen i tiden henimod den fuldkomne enhed med Gud.

Det er ifl. Gr. "ubegribeligt", hvordan det skulde være muligt at ophæve det faktum, den kendsgerning (som Grundtvig vilde sige), at mennesket har forsøgt at opnå viden om, hvad der er 
godt, og hvad der er ondt, eller i det mindste at det har gjort både onde og gode gerninger, både bevidst og ubevidst og både med viden og uden viden om, hvad der er godt, og hvad der er ondt. Det er nemlig karakteristisk for mennesket at have en "moral " eller "etik" - ved siden af den Lov, som er optegnet i Det gamle Testamente, og som ifølge Paulus i Det nye Testamente "er indskrevet i menneskenes hjerter" (Rom. 2. 14-15) af Gud. Og "Faldet " består netop deri, at mennesket ikke gør det gode, selv om det véd, hvad der er godt, ja endog selvom det gerne vil gøre det gode. "Det gode, som jeg vil, det gør jeg ikke, og det onde, som jeg ikke vil, det gør jeg. " (Rom. 7.19) Det er denne tilstand, Søren Kierkegaard kalder "Angest" og beskriver i sin bog herom. Det er også beskrevet $\mathrm{i}$ en moderne bog med denne titel (af Thorkild Vanggaard), og begge bøger er skrevet som psykologiske undersøgelser. Grundtvig giver ikke en psykologisk beskrivelse eller undersøgelse. Han regner med, at enhver kender denne psykologiske tilstand fra sig selv og karakteriserer den som en "Trylleskov". Han kalder det "ubegribeligt", hvordan den oprindelige hensigt med menneskets skabelse skulde kunne opnås. Men han erkender samtidig den historiske kendsgerning, at Jesus har levet og forkyndt, at Gud har tilgivet dette fald, og at dette evangelium er blevet troet af de kristne - trods dets ubegribelighed. Altså en hårdnakket kendsgerning, der er ubegribelig.

Grundtvig er altså kommet frem til sin opfattelse af mennesket, ikke ved psykologiske iagttagelser eller beskrivelser, men ved at kombinere sin historiske viden med sin psykologiske viden - og ved at anvende denne kombinerede viden til at tolke den menneskeopfattelse, han finder $i$ Det gamle og Det nye Testamente. Dette fremgår dels af hans Verdenskrønike 1814, dels af hans filosofiske Betragtning "Om Mennesket i Verden “, trykt i Danne-Virke 1817 og først genoptrykt i 1983. En udførlig gennemgang af denne centrale afhandling eller "Betragtning " vilde blive for omfattende til dette foredrag; men det er her, man finder de blivende træk i Grundtvigs menneskesyn. Kun hans holdning til videnskaberne har efter min mening forandret sig i 1832. Jeg skal derfor nøjes med her at sammenfatte de træk fra denne afhandling, jeg betragter som de fundamentale eller blivende træk.

Det drejer sig om ialt 9 punkter: 
1. Mennesket er på én gang betragtet fra et kristent og et ikkekristent synspunkt, i den hensigt at gøre Bibelens skabelses- og frelsestanke forståelig for en rent filosofisk og psykologisk tankegang i overensstemmelse med erfaring og sund menneskeforstand.

2. Mennesket er ved hele sit sanseapparat direkte beslægtet med dyrene, og dets historiske udvikling er en fortsættelse af dets adskillelse fra dyrene - en udvikling, der former sig forskelligt i de forskellige folkeslag. Men der er end ikke antydet nogen raceteori i essayet "Om Mennesket i Verden".

3. Gudsbilledet i mennesket er stadig til stede trods det fald, hvis realitet bekræftes såvel i den daglige erfaring hos ethvert menneske som i historien. Faldet består i en afvigelse fra Sandheden, som har skabt mennesket - en afvigelse, fremkaldt af Lognen, som tilintetgør mennesket. Sandhed og Løgn ses som de åndelige realiteter, der ligger bag den legemlige realitet, vi umiddelbart sanser, og dermed bag liv og død.

4. Grundtvig giver i sit essay "Om Mennesket i Verden" to forskellige forklaringer af, t,vad han forstår ved Aanden i mennesket (eller med hans egen sprogbrug "Menneskets aandige Forhold "). Et sted siger han, at Aanden er "blandede Forestillinger af sandselig Oprindelse, men med aandigt Præg ", hvilket røber sig ved, "at de kun have en billedlig Skikkelse, vise sig under Billedet af de sandselig tilsvarende Ting " (s. 188). Et andet sted (s. 168) siger han: "hvad jeg forstaar ved Aand" er "nemlig en levende, virksom og kraftig Forestilling, der hverken i sig selv eller i sin Virkning kan sandses, men kun erfares i Selvbevidstheden «. Det drejer sig her om at forklare viljen, og det er derfor mere virkningen end oprindelsen, Grundtvig her vil give en psykologisk forklaring af. Men de to forklaringer strider ikke mod hinanden. Det for Grundtvig karakteristiske ved dem begge to er, at han undgår fremmedord som $\mathrm{fx}$. ordet "Idee" og i stedet taler om forestillinger, der ganske vist tilsyneladende har en sanselig (sansbar) skikkelse, men kun har billedlig betydning og derfor har "aandigt Præg".

5. Skabelsen af mennesket og verden forudsættes som en given realitet $\mathrm{i}$ overensstemmelse med erfaring og sund menneskeforstand. Da denne realitet er i overensstemmelse med modsigelsens grundsætning (kontradiktionsprincippet), som for 
Grundtvig er "Sandhedens Grundlov", bruger Grundtvig det udtryk, at det er Sandheden, der ved sin Aand har skabt verden og mennesket. - Dette er for Grundtvig ingen trossag, men simpelthen virkelighedserkendelse. At Immanuel Kant har nægtet at anerkende denne erkendelsesteoretiske realisme, går Grundtvig ikke ind på her. Han finder, at det er galskab at benægte sin egen selvbevidsthed, eller at hævde at man selv har været til fra evighed af. Altså må man være blevet til. Både mennesket og verden er begrænset i tid. (Ved fødsel og død eller ved skabelse og tilintetgørelse.) Dette er Grundtvigs hovedforudsætning. Den blev ham indlysende i oktober 1813, da han skrev manuskriptet "Om Menneskets Vilkaar" (Værker i Udvalg II, s. 241ff, specielt s. 266).

6. Faldet derimod forudsætter, at mennesket er skabt i Guds billede efter hans lignelse ifølge Bibelen, men at det er afveget fra sit - som det her hedder - "statholderlige Forhold", hvori det stod og står til Skaberen. Det forudsætter m.a.o. den tro, at hensigten med dets skabelse er, at det skal ligne Skaberen, at mennesket altså ikke er sin egen herre, men underordnet Skaberen. Når mennesket i stedet opfatter sin tilsyneladende selvstændighed (evnen til selv at vælge sine handlinger), som det virkelige, fundamentale forhold og ikke som det blotte billede af eller den ufuldkomne lighed med Skaberen, underkaster det sig Løgnen og mister det ved skabelsen givne liv i døden.

7. Det er for den menneskelige tanke umuligt at indse, hvorledes mennesket selv ("Sjælen") skulde kunne frelses fra den absolute tilintetgørelse, når mennesket påstår at have en uafhængighed, som det i virkeligheden ikke har. Det er en fristelse, som er forståelig, men som uundgåelig må medføre tilintetgørelse. "... men hvorledes der skulde skee en Udvikling, hvorved Sjalen frelstes og fik Opreisning, det er ubegribeligt, og kun saameget kan man sige, at det maatte gaa forunderligt til, thi i Menneskets egne Øine er det en Umulighed. " (S. 165.) - Dette er den eneste måde, hvorpå Grundtvig i dette essay anvender begrebet under. At mennesket "er faldet og falder idelig af sig selv", dvs. fra sig selv, "og kan idelig opreise sig selv, og falder dog tilsidst i Graven hvor han bliver liggende", har altid (selv i de tidligste optegnelser) forekommet Grundtvig at være en uforståelig opfattelse af menneskelivet. Han kalder det her 
simpelthen en "Selv-Modsigelse" - "kort sagt at Intet er Noget og Noget er Intet" (s. 167). Det er måske selvmordets begrundelse og virkelighed, Grundtvig her forholder sig til. Han finder kun én løsning: den at ét menneske aldrig er faldet for denne fristelse og derfor heller ikke har kunnet fastholdes af døden, selv om det blev dræbt. Ét sådant menneske siger Grundtvig at han kender, kun denne ene, som har sagt, at mennesket frelses ved at tro på ham. Dette er Grundtvigs enkle forklaring på forløsningen ved Jesus Kristus. Men han bruger $i k k e$ dette teologiske udtryk. Han beskriver kun den menneskelige situation. Men fornægter ikke sin tro.

8. Det faldne menneske udvikler sig som følge af denne tro trods faldet - stadig hen imod sin oprindelige bestemmelse: at ligne sin skaber mere og mere. Men forudsætningen for, at denne bestemmelse kan realiseres eller at denne hensigt kan virkeliggøres, er at mennesket valger at tage Sandheden ist.f Lognen til sit forbillede - såvel $\mathrm{i}$ sine handlinger som $\mathrm{i}$ den ydre og indre sansning af verden og sig selv. Og ved den indre sansning forstår Grundtvig 1. "Indbildningskraften " dvs. forestillingsevnen, det indre syn, 2. "Følelsen" med "Selvfølelsen" som midtpunkt i "Hjertet " 3. "Forstanden ", dén indre hørelse, hvormed man forstår ordene, og hvormed man kan skelne mellem, hvad man kan "begribe", og hvad man kun kan "fatte", dvs. have en delvis forståelse af. Kun hvad der "klart er indtraadt i vor Selv-Bevidsthed have vi begrebet ". Og mennesket kan derfor "ikke begribe noget Større end sig selv". (S. 195.) - Det er derfor ganske naturligt, at mennesket gør sig billedlige forestillinger om, hvad det ikke kan fatte, endmindre begribe. Det er derimod urimeligt, at det skulde kunne gøre sig klare begreber om, hvad der er større end det selv, selvom det kan have stærke folelser over for dette. - Når Grundtvig taler om Skaberen eller Gud, kan han derfor kun gøre det i billedlige udtryk, og han finder at det ikke blot strider mod sund fornuft, men også at det er en fristelse til at gå ud over menneskets grænser, at gøre sig klare begreber om Gud i abstrakte vendinger. Derimod finder han det ikke blot muligt, men også $i$ overensstemmelse med menneskets bestemmelse at opfatte sig selv som et billede på sin skaber. Hovedsagen er, at mennesket kun opfatter sig som et ufuldkomment billede, en endnu langtfra fuldt ud- 
viklet skabning. Denne menneskeopfattelse er det kun muligt at komme frem til og videreudvikle gennem historieforskningen, især ved studiet af, hvordan mennesket har udviklet sig gennem poesi, kunst og videnskabelighed (dvs. filosofi og videnskab).

9. Poesi, kunst og videnskabelighed er i følge Grundtvig de veje, ad hvilke mennesket arbejder sig hen imod sit mål, som er at forenes i kærlighed med Sandheden, som har skabt mennesket med den bestemmelse at blive et mere og mere fuldkomment billede af den (Sandheden) selv. Der gives ifølge Grundtvig ingen genvej til at nå dette mål - som f.eks. en mystisk oplevelse, en "ren Natur-Anskuelse" eller en "intellektuel Anskuelse", omend man i korte øjeblikke kan opleve noget sådant. Forveksler man sådanne oplevelser med målet, lader man sig bedrage af "glimrende Skygger ", dvs. af de illusioner, hvormed Løgnen modarbejder Sandheden i mennesket. Det er disse illusioner, der bevirker, at "vi, som Narre, der see halvgjort Arbejde, knurre over, at det halve ikke er det Hele" (s. 201). - I den nyere tid har man gjort naturvidenskaben til grundlag for alle andre videnskaber og fornuften til grundlaget for menneskeopfattelsen, mens fantasi og følelse blev forvist fra sandhedserkendelsen, skønt al sand erkendelse af mennesket i den virkelige verden må begynde med den ydre sansning af vort legeme og genstandene omkring os, som vi ikke kan forestille os, ordne og samle uden det indre syn, som samtiden ligesom Grundtvig kaldte indbildningskraften. Denne indre sans omfatter både den modtagende sans og den virkende evne, hvormed vi genkalder, hvad vi har set. Følelse og fantasi er altså udgangspunkt for vor Selvbevidsthed, som er den egenskab, der adskiller mennesket fra dyrene. Fremgangsmåden i sandhedserkendelsen må derfor ifølge Grundtvig være en helt anden end den hidtil anvendte:

"Intet er os saa klart som vor Selv-Bevidsthed, og kan vi ikke begribe den, bare vi os nok for at begribe noget Andet, først den, saa vore, det vil sige, Menneskets Forestillinger og Følelser i Historien, saa vort Legeme, og derpaa de udvortes Ting, det er Gangen; hvorvidt vi kan overkomme den, bliver et Spørgsmaal, men at vi ved at lade den fare, give Afkald paa alle sande Begreber om os selv og Verden, det er aabenbart. " (S. 197.) 
Det er udfra dette - man kunde kalde det "antropologiske" synspunkt, Grundtvig betragter de to "Afdelinger" af "Vidskabs Vei», "Historien og Naturen".

Det syn på videnskaberne, Grundtvig i denne filosofiske betragtning udleder af sit menneskesyn, er ikke hans endelige og blivende. Først og fremmest derved, at han i 1817 stadig så det som historievidenskabens sag at give "det store uigendrivelige Beviis paa Christendommens Sandhed" (s. 201). Det ses heraf, at Grundtvig i 1817 ikke drog det skel mellem "Tro og Vidskab», han i 1833 siger, at han "først efterhaanden" har lært at drage (Haandbog i Verdens-Historien, fortalen US VI s. 12). Han skelner derfor ikke mellem de sandhedsbeviser, som erfaringen og den sunde menneskeforstand nøder enhver til at indse, og den Sandhed (med stort S), som mennesket overbevises om ved sin frivillige tro. - Alligevel forbliver det et vasentligt trak $i$ Grundtvigs menneskesyn, der ses allerede $\mathrm{i} 1817$, at han samtidig med at fastholde, at mennesket er skabt i Guds billede, ser mennesket som beslægtet med dyrene ved sine sanser og udviklet gennem historien $i$ analogi med det enkelte menneskes udvikling gennem barndom, ungdom og alderdom, således at indbildningskraftens og folelsens udvikling går forud for forstandens. Det antydes også, at dels selvfølelsen, dels kærligheden er fundamentale for udviklingen af selvbevidstheden, og at det dels er herved, dels ved sit sprog, at mennesket adskiller sig fra dyret.

Der er næppe grund til at undre sig over, at Grundtvig med et menneskesyn, der adskilte sig så afgørende fra det i samtiden dominerende, var afskåret fra en stilling som universitetslærer i historie. Snarere må man undre sig over, at han fire år senere uventet fik stilling som sognepræst i Præstø. Men det skrift, hvormed han derpå fire år efter erklærede universitetsteologien krig, Kirkens Gienmale 1825, forklarer den frygt, man nærede for Grundtvig. Først da han i 1831 indså, at tro og viden bygger på to forskellige former for overbevisning, blev det ham muligt at slutte fred med anderledestænkende. Menneskesynet forelå imidlertid i sine hovedtræk allerede i Danne-Virke 1817.

Er det overhovedet muligt for moderne tænkende mennesker at forstå og bruge dette menneskesyn? 
For Grundtvig var der ingen strid mellem den tanke, at mennesket er skabt i Guds billede, og den tanke, at mennesket er beslægtet med dyrene og stadig udvikler sig mod større og større lighed med Gud. - At mennesket er skabt, såvel som hele den øvrige verden, var Grundtvig aldrig i tvivl om. - Den tanke, at mennesket og verden skulde have kunnet udvikle sig af intet, og at mennesket selv skulde kunne udvikle sig til at blive hele verdens herre, var for ham en tanke, der stred imod sund fornuft. $\mathrm{Og}$ dog har denne tanke i Grundtvigs samtid og eftertid vundet større og større udbredelse. Det var og blev efter Grundtvigs opfattelse simpelthen en Løgn, en tilsyneladende stærk, men i virkeligheden afmægtig protest mod Guds Sandhed. Som det hedder i salmen:

Afsiger Løgnen Du,
Og troer Guds Sandhed nu?

Den strider ifølge Grundtvig mod sund fornuft. Det er kun en syg "Krøblinge-Forstand ", der falder for den.

Men Grundtvig indså i 1832, at der var mennesker, som vel indså, at de var skabt og fristet og faldet for fristelsen, men som mente, at det var menneskets egen opgave at rejse sig fra dette fald og udvikle sig videre hen imod lighed med Gud og herredømme over verden i overensstemmelse med Guds hensigt. De mente altså, at mennesket selv kunde helbrede sin tilskadekomne natur. Han kaldte dem naturalister "med Aand", og dem vilde han gerne holde "Skole" med, men ikke "Kirke", dvs. han kunde godt samarbejde med dem i videnskabelig, pædagogisk og politisk henseende, men ikke i religiøs henseende. Dette gælder først og fremmest hans modstander i Kirkens Gienmæle, H. N. Clausen.

Men er det overhovedet muligt for moderne tænkende mennesker i dag at forene den religion, som forudsætter, at mennesket er skabt i Guds billede, og faldet for den fristelse at tilegne sig viden om godt og ondt for at handle efter denne sin egen moral - at forene denne ægte kristendom med en naturalistisk eller idealistisk menneskeopfattelse? - Ja, det konstaterede Grundtvig som sagt, at de fleste af hans samtidige gjorde. Men han vilde ikke kalde dem æg- 
te kristne. Han hævdede, at kun den tro, han havde fået på frelsen ved Kristus i daben og nadveren, var agte kristendom.

Grundtvig fandt m.a.o., at hans egen opfattelse af forholdet mellem moral og religion var det eneste sande, men at der var mennesker, som kaldte sig kristne, der ikke havde indset dette. At tvinge dem til at antage hans tro, var ikke blot umuligt, men også stridende mod en kristen menneskeopfattelse. For Gud havde skabt mennesket med frihed til at tilegne sig al kundskab. Det var dette, der vistes i myten ved at Adam gav dyrene navne. Men kundskaben om godt og ondt advarede Gud Adam imod, fordi den vilde medføre døden. Hvorfor? Fordi den forudsatte en udvikling, mennesket endnu ikke var modent til. At mennesket nu skulde være nået til denne modenhed, benægtede Grundtvig. Han betegner menneskets forhold til sig selv som "statholderisk «: Dets forhold til legemet er ganske vist "kongeligt ", men dets forhold til ånden "tjenerligt ", idet menneskets ånd er indblæst af Gud.

Grundtvigs menneskesyn er og forbliver altså i bund og grund kristent, ligesom hans historiesyn er og forbliver "den mosaiskchristelige Anskuelse af Menneskelivet $\mathrm{i}$ alle dets Retninger og alle dets Yttringer " (for at citere Fortale til Haandbog i VerdensHistorien, 1833). Jeg har andensteds brugt udtrykket "det bibelske historiesyn ", men meningen er nøjagtig den samme. Men der er to spørgsmål, som rejser sig mht. hans menneskesyn:

1. hvorledes forholder dette kristne menneskesyn sig til den nordiske mytologi, som var Grundtvigs hovedinteresse før 1810?

2. hvorledes forholder dette menneskesyn sig til den "Græske Betragtning af Menneske-Livet og Historien ", som Grundtvig i 1833 siger at han nu foretrækker "til Skole-Brug" - dvs. pædagogisk og videnskabeligt, uden for kirken?

Disse to spørgsmål ser jeg mig ligefrem nødsaget til at besvare, fordi de står uløst, når man slutter sig til den klare udtalelse af Grundtvig i 1833, at den mosaisk-kristelige anskuelse af menneskelivet "nu som før " er ham "den eneste guddommelige sande og eviggiældende“. Men jeg kan kun gøre det ganske kort.

Svarene ligger for mig at se også i Danne-Virke, altså i 1817. Mht. den nordiske mytologi ligger svaret dels i artikelen "Om Oldgrandskning ", der udtrykker et anderledes nøgternt forhold 
til den nordiske mytologi end det, Grundtvig havde før 1810, dels i artikelen "Om Bjowulfs Drape", som er en gennemgang af hele digtet, der viser, at det ganske vist beskriver en kamp mod onde magter, men ikke i strid med det kristne menneskesyn. - Mht. til "den Græske Betragtning af Menneske-Livet og Historien", så viser det sig i artikelen "Om Mennesket i Verden", at den grundbetragtning af menneskelivets udvikling i analogi med det enkelte menneskes udvikling, gennem barndom, ungdom og alderdom, som Grundtvig bruger i Haandbog i Verdens-Historien, allerede er skitseret i artikelen "Om Mennesket i Verden".

Jeg vil gerne hertil føje den bemærkning, at den platoniske betragtning af digteren som et inspireret menneske, der udtaler guddommelige ord, som han egentlig ikke selv forstår, i en slags enthusiasmos, hos Grundtvig efter 1810 er forbundet med hans kristne menneskesyn på en måde, som han især har belyst ved sin gennemgang af fortællingen om profeten Bileam, der var bestilt til at forbande Israels folk, men fordi han var inspireret af Gud, ikke kunde andet end velsigne det. Grundtvig gennemgår fortællingen i sin Verdens-Krønike 1814. Grundtvig har altså også på dette punkt stillet sit kristne menneskesyn i forhold til ikke-kristne tanker om mennesket. - Når han gjorde det, var det ikke blot fordi han ønskede at mægle mellem sine forskellige standpunkter før og efter 1810, men også fordi han vedblev at have et positivt forhold til den nordiske mytologi og den græske opfattelse af poesien.

Der er ingen tvivl om, at Grundtvigs menneskesyn er fremgået af en række opgør med ham selv, som Kaj Thaning træffende udtrykker det. Men disse opgør var ikke blot koncentreret om 1832, De er lige så meget koncentreret om 1810. Det har i 1832 været en stor befrielse for Grundtvig at have skrevet en ny Nordens Mythologi, der ikke stillede sig selv i stedet for det kristne menneskesyn - som om vi skulde vende tilbage til en før-kristen menneskeopfattelse - men som det hedder i titelen kun var et "SindbilledSprog", som han her havde "udviklet og oplyst", dels historisk, dels poetisk. Og da det var gjort, skrev han så den indledning, der indeholder hans endelige udtryk for sit menneskesyn. Det er set $\mathrm{i}$ modsætning til den stive, statiske opfattelse af mennesket, som man stadig tillægger kristendommen og Bibelen. Som om udvik- 
lingstanken var i strid med skabelsestanken. Som om Gud havde skabt alle væsener færdige, til en uforandret tilværelse, skønt historien viser, at de har forandret sig meget. Og som om det vilde være en lykke for os, om vore efterkommere lignede os som et stereotypt aftryk - Grundtvig oversætter lithografi til "Steentryk " - eller som om mennesket bare var en abe, der efterlignede andre dyr. Nej - "Naar man virkelig er klog, vil man altid gierne blive klogere, og lærer derfor af Fiender saavelsom af Venner".

"Er vi derfor saa forfængelige, at vi vil giøre vore Børn og hele Efterslægten til et Steentryk af os i Legems-Størrelse, da giør vi os selv en stor Skam og giør ... Efter-Slægten ulykkelig, fordi Mennesket er ingen Abekat, bestemt til først at efterabe de andre Dyr og siden sig selv til Verdens Ende, men han er en mageløs, underfuld Skabning, ... som et guddommeligt Experiment, der viser, hvordan Aand og Støv kan giennemtrænge hinanden og forklares i en fælles guddommelig Bevidsthed. "- En skabning "i hvem guddommelige Kræfter skal kundgiøre, udvikle og forklare sig giennem tusinde Slægter" - og ikke sådan en "kloning", som man nu forsøger på at frembringe, ved hjælp af gen-teknologien.

Det er mennesket, der forsøger på at sætte udviklingen i stå ikke den skaber, som Bibelen og Grundtvig forestiller sig. Men det er ikke med ét slag, Grundtvig er kommet frem til denne menneskeopfattelse. Det er gennem sin kritiske betragtning af den europæiske kulturs historiske udvikling i de tre Verdenskrøniker, og de filosofiske betragtninger, han har gjort sig samtidig fra 1813 til 1818 - og som fik deres endelige form i Danne-Virke. - De teologiske betragtninger, som førte til Kirkens Gienmale, dommen for injurier og censur, satte ham tilsyneladende i stå. Men Englandsrejserne og samtalen med Clara Bolton, der - som Thaning har vist - var et højtdannet, religiøst toenkende og folende menneske, satte ham i gang, så han turde vove at nærme sig den hedenske religion, han havde været nær ved at blive opslugt af $i$ 1805-10. Og - ikke mindst - at udtale de ord, som gjorde det muligt for ham at sige "Menneske først - og Christen saa — nemlig følgende:

"mange Hæders-Mænd, som ingenlunde dele min Tro eller billige mi- 
ne Tanker ... agte det, med mig, for en Grund-Sætning, alle ærlige, ædle og ægte kraftige Naturer maae have tilfælles: aldrig at snoe sig fra sine Ord, eller skye Opoffrelser for sin Overbeviisning, men altid at unde Næsten samme Frihed, som Man selv giør Krav paa, og altid at lade haant om kiødeligt Ryg-Styd i aandelig Kamp!«

Sådan sluttede Grundtvig nemlig sit lille skrift "Om den Clausenske Injurie-Sag" i 1831. Og derefter kom de skrifter, hvori han fremsatte både sine tanker om en folkelig højskole, og om verdenshistorien, og hvori han udgav sit Sang-Værk til den danske Kirke. Samtidig holdt han sine prædikener i FrederiksKirken og sine foredrag om Mands Minde. Og dermed havde han genvundet sin plads i den danske litteratur. Alle disse værker bærer præg af det menneskesyn, han havde arbejdet sig frem til i Danne-Virke, men afklaret og forståeligt for almindelige mennesker. Ikke i overensstemmelse med samtidens filosofiske systemer, men selvstændigt gennemtænkt fra bunden og hele tiden set i forhold til samtidens tanker, der var dybt forskellige fra hans. Det er derfor til Danne-Virke, man må gå, hvis man vil finde sammenhængen i Grundtvigs tankeverden. 